\title{
USAHA MIKRO KECIL DAN MENENGAH (UMKM) PADA MASA PANDEMI COVID-19 DI KECAMATAN SAKO PALEMBANG
}

\author{
Ong Berlian
}

\author{
Ilmu Administrasi Negara, STISIPOL Candradimuka, Palembang, Indonesia
}

ongkpusumselberlian@yahoo.co.id

Kata Kunci: [Program

Pemberdayaan Masyarakat, UMKM]

Published by:

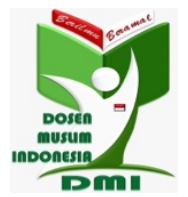

Copyright (C) 2021 The Author(s)

This article is licensed under CC BY 4.0 License
Abstrak: Pemberdayaan masyarakat merupakan kegiatan peningkatan partisipasi masyarakat dalam pemenuhan kebutuhan hidup dan menyelesaikan permasalahan yang dialami masyarakat. Hasil menunjukkan adanya respon positif pemerintah serta partisipasi aktif masyarakat yang tinggi. Tujuan kegiatan ini untuk mempromosikan dan meningkatkan kualitas produk agar dapat lebih berkembang dan mampu bersaing dengan industri UMKM lain pada saat pandemi Covid 19 ini. Guna meningkatkan pemberdayaan dan kesejahteraan masyarakat melalui kewirausahaan agar menjadi masyarakat yang mandiri dan berkembang melalui branding dan marketing produk terhadap peluang bisnis yang menjanjikan, karena banyak diminati oleh banyak kalangan. Selain itu beberapa luaran yang dihasilkan: (1) Peningkatan daya saing dan penerapan iptek di masyarakat berupa pengetahuan packing produk menggunakan desain modern, alat dan plastik tas press serta teknik pemasaran Internet Marketing; (2) menjembatani dan mengajak 30 pelaku UMKM bergabung dengan Asosiasi Pencinta Kue dan Kuliner (Aspenku) Provinsi Sumatera Selatan; (3) Peningkatan kualitas, daya saing dan nilai tambah produk kue dan kuliner; (4) HaKI berupa Desain Produk Industri Rumah Tangga seperti; kuliner (kripik, jamu, pempek, kerupuk, kemplang, kacang), cinderamata, pakaian dan masih banyak lagi.

\section{(cc) $\mathrm{BY}$}

https://dmi-journals.org/jai 


\section{Pendahuluan}

Upaya pemberdayaan masyarakat merupakan upaya meningkatkan partisipasi masyarakat dalam rangka memenuhi kebutuhan hidup dan menyelesaikan permasalahan yang dialami masyarakat dan dilakukan berdasarkan kearifan dan potensi lokal, upaya peningkatan pengetahuan dan keterampilan melalui seminar dan diskusi UMKM. Kegiatan dilaksanakan sesuai dengan prosedur dan model pemberdayaan partisipatif telah dilaksanakan diantaranya pemberdayaan produk industri rumah tangga seperti; kuliner (kripik, jamu, pempek, kerupuk, kemplang, kacang), cinderamata, pakaian dan masih banyak lagi.

Sinergitas pemerintah daerah, perguruan tinggi swasta, dan masyarakat menjadi salah satu kunci keberhasilan program pengabdian masyarakat. Perguruan tinggi menjadi instrumen utama dalam melahirkan kualitas sumberdaya anak bangsa yang kreatif dan inovatif. Tri Dharma Perguruan Tinggi melalui eksistensi pendidikan pengajaran, penelitian ilmiah, dan pengabdian pada masyarakat kemudian menjadi bingkai pengembangan Iptek yang dikemas dalam kegiatan KKN.

KKN merupakan suatu bentuk pendidikan/pengabdian dengan cara memberikan pengalaman belajar kepada mahasiswa untuk hidup di tengah masyarakat, secara langsung mengidentifikasi dan menangani permasalahan masyarakat serta upaya meningkatkan isi dan bobot pendidikan/pengabdian bagi mahasiswa serta untuk mendapatkan nilai tambah yang lebih besar bagi perguruan tinggi. Bagi perguruan tinggi penyelenggaraan KKN dilaksanakan dengan maksud meningkatkan relevansi pendidikan tinggi dengan perkembangan dan kebutuhan masyarakat akan Iptek dan Seni untuk melaksanakan pembangunan serta meningkatkan persepsi mahasiswa tentang relevansi antara materi kurikulum di kampus dengan realita pembangunan dalam masyarakat.

Secara eksplisit, hal-hal yang dapat dicapai melalui kegiatan ini: (1) melatih dan memberikan pengalaman belajar bagi mahasiswa dalam memberikan konstribusi dengan mengubah paradigma pembangunan menjadi pemberdayaan masyarakat; (2) menumbuhkan kepribadian dan meningkatkan wawasan dan pola pikir mahasiswa; dan (3) mendekatkan Perguruan Tinggi kepada masyarakat.

Adapun sasaran dan manfaat penyelenggaraan Pemberdayaan Masyarakat dengan ikut keikutsertaan Masyarakat: (a) memperdalam cara berpikir dan bekerja secara interdisipliner; (b) menghayati dan mengerti kesulitan yang dihadapi oleh masyarakat; dan (c) melatih mahasiswa sebagai dinamisator dan problem solver. Kemudian bagi Masyarakat dan Pemerintah Daerah; (a) memperoleh metode baru dan bantuan pemikiran untuk merencanakan, merumuskan, dan melaksanakan pembangunan; (b) memberi pengalaman dalam menggali serta menumbuhkan potensi swadaya masyarakat sehingga mampu berpartisipasi aktif dalam pembangunan; dan (e) memperoleh sumbangan pemikiran mahasiswa dalam melaksanakan program pembangunan sebagai tanggung jawabnya.

Bagi Perguruan Tinggi, melalui kegiatan ini dapat (a) memperoleh umpan balik sebagai hasil perintegrasian mahasiswa dengan masyarakat, sehingga kurikulum dan pengembangan Iptek dapat lebih disesuaikan dengan tuntutan nyata pembangunan; (b) melalui kegiatan mahasiswa, dapat menelaah dan merumuskan kondisi nyata bagi pengembangan Iptek, serta dapat mendiagnosa secara tepat kebutuhan masyarakat, 
sehingga Iptek yang diamalkan dapat sesuai dengan tuntutan nyata, (d) meningkatkan, memperluas, dan mempererat kerjasama dengan instansi serta departemen lain melalui rintisan kerjasama mahasiswa yang melaksanakan kegiatan Pemberdayaan Masyarakat.

\section{Metode Pelaksanaan}

\section{Tempat dan Waktu}

Kegiatan pengabdian masyarakat dalam bentuk KKN Tematik ini dilaksanakan selama periode bulan September-Oktober 2021, bertempat di 4 (empat) Kelurahan yakni Kelurahan Sialang, Kelurahan Sako, Kelurahan Sako Baru, Kelurahan Sukamaju dalam wilayah Kecamatan Sako Palembang.

Tabel 1. Waktu Kegiatan

\begin{tabular}{|l|l|l|}
\hline \multirow{2}{*}{ Jenis Kegiatan } & \multicolumn{2}{|c|}{ Bulan } \\
\cline { 2 - 3 } Survey Lapangan & September & Oktober \\
Perkenalan langkah awal & & \\
Pemilihan Lokasi dan & & \\
Khalayak Sasaran & & \\
Sosialisasi kegiatan & & \\
Edukasi serta pendampingan & & \\
praktek secara langsung & & \\
\hline Masyarakat mandiri dan & & \\
menghasilkan produk & & \\
\hline $\begin{array}{l}\text { Produk sudah bisa terlihat } \\
\text { dan dapat dikonsumsi }\end{array}$ & & \\
\hline
\end{tabular}

Sumber: Diolah Penulis Tahun 2021

\section{Khalayak Sasaran}

Mitra yang dilibatkan dalam kegiatan ini adalah Asosiasi Pengusaha Kue dan Kuliner (Aspenku) Provinsi Sumatera Selatan, Camat Sako Palembang, Lurah Sialang dan sasaran khusus adalah 30 pelaku UMKM.

\section{Metode Pengabdian}

Kegiatan Pemberdayaan Masyarakat dilaksanakan dengan melakukan kegiatan pelatihan, pendampingan serta penyuluhan dalam membuang sampah pada tempatnya. Kegiatan yang dilaksanakan meliputi, Pemberdayaan masyarakat untuk peningkatan perubahan pola pikir masyarakat agar berkembang dan bertahan di masa pandemi covid 19, dan Pelestarian lingkungan dengan memakai sampah atau sisa kain bekas yang ada dirumah. Secara rinci metode pelaksanaan kegiatan diantaranya yaitu:

1. Kajian Literatur dilakukan untuk mengetahui beberapa hal mengenai Program Kampung Iklim seperti: Adaptasi, dan Mitigasi.

2. Survei Lokasi menjadi langkah awal supaya kegiatan dapat berjalan lancar.

3. Sosialisasi di awal kegiatan kepada Ketua RT 19 dan RT 65, terkait tujuan kegiatan, tahapan kegiatan dan jadwal kegiatan.

4. Edukasi secara tatap muka terhadap Masyarakat yang berjumlah 23 orang, dalam kegiatan dibagi menjadi beberapa kelompok kecil. 
5. Membangun kembali karakter bangsa indonesia dari Pancasila yaitu Gotongroyong. Bersama-sama warga dan Mahasiswa membangun lingkungan yang bersih dan hijau. Saling menjaga kelestarian lingkungan rumah untuk membuang sampah pada tempatnya dan menjadikan barang plastik bekas menjadi barang yang bermanfaat.

6. Pendampingan dan Prakter Langsung

Penyelesaian masalah ini tidak semata-mata dilakukan hanya untuk kebutuhan penulisan, namun dilaksanakan secara langsung dengan pendampingan anak pertanian dan praktek langsung dilakukan selama kurang lebih 30 Hari.

\section{Indikator Keberhasilan}

Indikator keberhasilan ditunjukkan adanya respon positif pemerintah setempat, Bank Sumsel Babel Capem Sako dan partisipasi aktif masyarakat dalam kegiatan, seperti pada saat pelaksanaan tatap muka dan seminar UMKM yang bertajuk tema Ekonomi Kreatif yang berjudul: "UMKM Tetap Kokoh Dimasa Pandemi" menjembatani antara Asosiasi dengan pelaku UMKM Di Kecamatan Sako khususnya Di Kelurahan Sialang.

Indikator keberhasilan lainnya adalah luaran yang dihasilkan antara lain:

1. Pertukaran informasi, promosi yang menarik dan trick marketing maupun koordinasi mencari inovasi-inovasi baru sehingga mampu bersaing dengan produk kue dan kuliner lainnya diera milenial dan disaat pandemi ini tetap eksis dan pendapatan meningkat.

2. Peningkatan daya saing dan penerapan Iptek berupa packing produk menggunakan desain modern dan alat press plastik serta teknik pemasaran Internet Marketing;

3. Keberadaan 30 kelompok usaha yang didampingi pengurusan Surat Izin Usaha, rencana penyediaan tempat usaha, prosedur kredit modal dari Bank Sumsel Babel Capem Sako;

4. Penyerahan oven alat pemasak kue/kuliner;

5. HaKI berupa Desain Produk Kue dan Kulner;

6. Adanya peningkatan motivasi dan antusiasme peserta, dengan melihat keberhasilan berupa beberapa produk dan luaran yang dihasilkan pengusaha kue dan kuliner yang tergabung dalam Asosiasi Pengusaha Kue dan Kuliner (Aspenku) Provinsi Sumatera Selatan.

\section{Hasil dan Pembahasan}

Program kerja dibuat dan dilaksanakan untuk memecahkan berbagai masalah yang dihadapi masyarakat. Program kerja tersebut dilaksanakan serentak dan berjalan secara bersamaan di beberapa lokasi di wilayah Kecamatan Sako Palembang. Kegiatan dikemas dan dilaksanakan selama KKN dengan berbagai tujuan berdasarkan bidang yang telah ditentukan.

1. Program kerja bidang sosialisasi, dimaksudkan untuk memberikan informasi tentang keberadaan STISIPOL Candradimuka Palembang, kegiatan-kegiatan KKN yang akan dilakukan kepada masyarakat maupun mitra. Program kerja ini dibuat dan dilaksanakan untuk menjelaskan salah satu tri dharma perguruan tinggi yakni pengabdian pada masyarakat dan upaya meningkatkan motivasi dan partisipasi masyarakat. 
2. Program pendataan penduduk yang terkait dengan upaya pencegahan covid-19 secara daring, yakni:

a. Pendataan jumlah penduduk berdasarkan usia, tingkat pendidikan, pekerjaan, dan lain-lain;

b. Pendataan penduduk yang masuk kedalam wilayah RT, RW tempat tinggal mahasiswa;

c. Pendataan kondisi ekonomi masyarakat yang bekerja/tidak bekerja;

d. Pendataan kondisi ekonomi pedagang/wiraswasta/supir/buruh/dll terdampak covid-19

e. Pendataan penduduk yang secara ekonomi tidak mampu.

3. Program edukasi pelaksanaan Kampung Iklim, meliputi;

a. Pembuatan dan sosialisasi media edukasi dari berupa gambar atau video berkaitan dengan tema KKN

b. Pembuatan poster/spanduk bekerjasama dengan masyarakat setempat melalui media; Whatsapp, Instagram, Facebook, Twitter, Youtube dan lainlain dengan tema Program Kampung Iklim (Kegiatan disesuaikan dengan kebutuhan masyarakat setempat)

c. Pembentukan Komunitas "Kampung Hijau" dan "Kampung Obat";

d. Menjadi mitra RT, RW, Kelurahan, Masyarakat dan komunitas dalam pelaksanaan program kampong iklim;

4. Program Kampung Iklim ini disesuaikan dengan kondisi lingkungan dan kebutuhan masyarakat yang berada dilingkungan setempat dikaitkan juga dengan tema pelaksanaan program kampung iklim. Bantuan kotak sampah dan alat protokol kesehatan, seperti; hand sanitizer, sabun, dan makser sebagai salah satu program kampong iklim untuk menjaga kebersihan lingkungan dan menjaga protocol kesehatan dimasa pandemic covid-19 di Kelurahan Sialang Palembang. Dan program cukup berhasil. Namun tidak adanya kegiatan monitoring dan evaluasi terhadap program ini setelah kegiatan KKN selesai, maka hasil keberlanjutan program tidak dapat diketahui. Program ini terselenggara atas adanya beberapa donatur dan penyumbang yang berkontribusi terhadap kegiatan dari persiapan sebelum ke lokasi KKN sampai kegiatan KKN berlangsung;

5. Sosialisasi Protokol Kesehatan melalui media sosial/online dilaksanakan untuk meningkatkan kepekaan dan kesadaran masyarakat terhadap pentingnya pencegahan penularan virus covid 19. Kegiatan dilaksanakan melalui media sosial/online dan mendapat respon positif dari masyarakat. Kegiatan ini mendapat dukungan dan support dari Lurah Sialang, Ketua RW/RT setempat.

6. Kegiatan ekonomi yang dalam program KKN yaitu Kewirausahaan Mandiri ini adalah membantu masyarakat di wilayah Kelurahan Sialang Kecamatan Sako Palembang dalam mengembangkan potensi usaha yang ada. Dalam hal ini pertama-tama kegiatan yang kami lakukan menemui pihak kelurahan yang ada melakukan wawancara mengenai kependudukan, demografis dan keadaan lingkungan sekitar. Observasi yang kami lakukan di wilayah Kelurahan Sialang ini menghasilkan bahwa potensi yang ada diantaranya makanan ringan, minuman tradisional dan berbagai macam usaha kuliner lainnya. Menurut hasil diskusi kelompok kami, usaha yang akan Menurut kami usaha ini mempunyai peluang untuk berkembang namun ada beberapa hal yang memang harus di evaluasi dan juga dikembangkan agar kedepannya lebih maju dan berkembang pesat dikalangan milenial. Selanjutnya kami melihat proses pembuatan hingga 
pengemasan dari kedua produk ini, dalam hal ini kami memberikan masukkan mengenai inovasi atau ide agar bisa produk tersebut bisa dikembangkan untuk bisa bersaing dengan produk-produk lainnya yang lebih modern. Untuk bagian promosi kita meningkatkan kualitas promosinya lewat sosial media dengan sistem yang apik, unik dan menarik minat pembeli. Kita membantu kebutuhan yang diperlukan oleh produk UMKM Kelurahan Sialang, kegiatan yang telah dilakukan dalam program KKN dengan tema Tips UMKM Tetap kokoh di masa pandemi adalah pengidentifikasian serta pengembangan UMKM yang memiliki potensi Kelurahan Sialang Kecamatan Sako Palembang. Tujuan dari kegiatan ini adalah untuk mempromosikan dan meningkatkan kualitas produk agar lebih berkembang. Serta dapat bersaing dengan industri UMKM lain pada saat pandemi covid-19. Dan guna meningkatkan pemberdayaan serta kesejahteraan masyarakat melalui KKN XXV. Kewirausahaan yang selanjutnya diharapkan dapat menjadi masyarakat yang mandiri dan bersaing pada era modern ini. Jadi Pengembangan yang kami lakukan dalam hal branding serta marketting produk. Peluang bisnis UMKM sangat menjanjikan di Kelurahan Sialang Kecamatan Sako Kota Palembang karena diminati oleh banyak kalangan.

\section{Luaran/Target}

Sebanyak 30 Pelaku UMKM yang ikut serta dalam seminar UMKM yang bertajuk tema Ekonomi Kreatif yang berjudul "Tips UMKM Tetap Kokoh Dimasa Pandemi “ yakni untuk menjembatani antara Asosiasi dan pelaku UMKM di Kelurahan Sialang. Mengajak ikut serta para pelaku UMKM untuk bergabung di Asosiasi Pencinta Kue dan Kuliner Sumatera Selatan (ASPENKU). Ada beberapa pelaku UMKM mulai dari penjual jamu, keripik, pempek, dan kacang yang ada di Kelurahan Sialang.

Program kerja bidang lingkungan meliputi pemberian kotak sampah, pembentukan komunitas "Kampung Hijau" atau "Kampung Obat", Mahasiswa KKN menjadi mitra RW, RT, kelurahan, masyarakat, komunitas pelaksanaan program "Kampung Iklim". Program-program kerja ini dibuat dan dilaksanakan untuk mendukung program pemerintah mengenai lingkungan hidup, seperti untuk menambah ruang terbuka hijau dengan melakukan penanaman pohon. Dengan melibatkan dan meningkatkan kesadaran masyarakat mengenai pentingnya membuang sampah pada tempatnya dan mengetahui dampak dari lingkungan yang kurang bersih, maka dilakukan kegiatan kerja bakti dengan pembersihan sampah-sampah plastik.

Program kerja terakhir adalah program bidang kesehatan meliputi program penyuluhan-penyuluhan tentang Perilaku Hidup Bersih dan Sehat (PHBS) dan penyuluhan bahaya rokok dan narkoba, Pembinaan Keluarga Sehat dan Penyuluhan Tanaman Obat Keluarga (Toga) Sosialisasi pencegahan Covid 19 melalui 5 M (Mencuci tangan, memakai masker, menjaga jarak, menjauhi kerumunan, mengurangi mobilitas. Program kerja dan kegiatan ini dilaksanakan sebagai upaya untuk meningkatkan pengetahuan pentingnya perilaku hidup bersih dan sehat, seperti makan sayuran dan mencuci tangan pakai sabun sebelum dan setelah makan, prilaku merokok dan penyalahgunaan narkoba.

Keberhasilan program kerja kesehatan dapat dilihat antusias siswa dan masyarakat dalam memberikan pertanyaan dalam kegiatan penyuluhan dan sosialisasi kegiatan. Antusias dan partisipasi yang besar sangat menggembirakan dan berharap berlanjut meski kegiatan telah selesai. Kemudian produk kegiatan berupa papan wicara 
yang diletakkan di tempat strategis sehingga memudahkan untuk dilihat dan dibaca oleh masyarakat setiap saat. Keberadaan papan wicara ini diharapkan tidak hanya sebagai himbauan akan dampak negatif berupa penyakit, tetapi dapat menurunkan dan menghilangkan prilaku masyarakat membuang sampah di sembarang tempat. Selain itu, dampak positif dari program kesehatan ini adalah adanya peningkatan pengetahuan tentang tanaman yang dapat dijadikan obat serta perilaku hidup bersih dan sehat di rumah tangga.

\section{Evaluasi Program Pengabdian Masyarakat}

Tindak-lanjut kegiatan secara formal sebagaimana pelaksanaan diawal sudah tidak ada lagi. Namun proses monitoring dilakukan dengan tetap melakukan komunikasi dengan pemerintah Kecamatan Sako, Kelurahan Sialang dan kelompok UMKM, tokoh masyarakat dan pemuda.

Hasil evaluasi secara menyeluruh bahwa kegiatan penyuluhan, pelatihan dan pendampingan kelompok memberikan dampak positif terkhusus kelompok usaha makanan ringan, minuman tradisional dan berbagai macam usaha kuliner lainnya. Keberhasilan program tidak terlepas adanya keterlibatan dan partisipasi aktif mitra selama kegiatan pengabdian berlangsung, seperti dukungan; Asosiasi Pengusaha Kue dan Kuliner (Aspenku) Provinsi Sumatera Selatan pemerintah kecamatan dan kelurahan serta masyarakat. Selain itu. melalui program kerja telah memberikan pengetahuan dan pemahaman yang signifikan bagi masyarakat, karena berbagai masalah telah berhasil diselesaikan.

Diharapkan pengetahuan dan keterampilan yang telah mereka dapatkan, mampu dijaga dan diterapkan secara menyeluruh dan berkesinambungan serta dapat lebih memotivasi produktivitas masyarakat.

\section{Kesimpulan}

Pengabdian masyarakat dengan KKN telah melaksanakan empat program kerja bidang ekonomi, pendidikan, lingkungan dan kesehatan sebagai upaya memecahkan masalah yang dihadapi masyarakat. Pelaksanaan program kerja mendapat respon positif dari pemerintah dan masyarakat sehingga semua berjalan lancar meski memiliki banyak rintangan.

Program-program kerja yang dilaksanakan juga menghasilkan beberapa luaran dan produk diantaranya: (1) Peningkatan daya saing dan penerapan Iptek di masyarakat berupa pengetahuan packing produk menggunakan desain modern, alat dan plastik press serta teknik pemasaran Internet Marketing; (2) terdapat 18 kelompok usaha yang didampingi pengurusan Surat Izin Usaha; (3) Teknologi Tepat Guna berupa penyerahan oven atau alat memasak kue kepada kelompok usaha kuliner; (4) Peningkatan kualitas, daya saing dan nilai tambah barang; (5) HaKI berupa Desain Produk Industri Rumah Tangga. 


\section{Ucapan Terimakasih}

Kami mengucapkan terimakasih kepada semua pihak yang terkait, kepada:

1. Bapak Dr. Amiruddin Sandy, M.Si., selaku Camat Sako Kota Palembang yang memberikan ruang kepada Dosen dan Mahasiswa/I untuk ikut serta Pengabdian Masyarakat.

2. Bapak Very Suparja, S.E., selaku Lurah Sialang, Kecamatan Sako Kota Palembang yang menyempatkan ikut serta hadir selama kegiatan berlangsung.

3. Bunda Raya, salah satu Penggiat UMKM di Kota Palembang

4. Seluruh Masyarakat yang telah hadir dan berpartisipasi selama kegiatan berlangsung khusus nya pelaku UMKM.

5. Tidak lupa, Seluruh Mahasiswa yang tidak bisa disebutkan satu persatu.

\section{Referensi}

D. Kasali, Rhenald. 2012. Kewirausahaan. Hikmah ; Jakarta

Kumorohadi, Untung \& Nurhayati. 2010. "Analisis Kualitas Pembinaan dan Pengembangan Jiwa Kewirausahaan di Kalangan Mahasiswa". Unsoed; Purwokerto

Meredith, G. Geoferry et al. 1996. Kewirausahaan; Teori dan Praktek. PT. Pustaka Binaman Pressindo; Jakarta

Tim Penulis. 2021. Buku Pedoman KKN Tematik Mahasiswa STISIPOL Candradimuka; Program Pelaksanaan Kampung Iklim; Palembang

Anomin. 2021. Laporan Akhir KKN Tematik Mahasiswa STISIPOL Candradimuka; Palembang 